\title{
Mycopathological Studies on Vigna radiata (L.) Wilczek (Green gram) from Patur, Dist. Akola (MS), India.
}

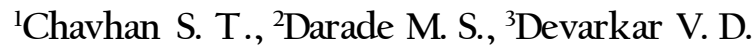 \\ ${ }^{1}$ G.N. A. Science College, Barshitakli- 440001 (MS) India \\ ${ }^{2}$ Govt. Vidarbha Institute of Science and Humanities, Amravati-444604 (MS) India \\ ${ }^{3}$ Shri Chhatrapati Shivaji College, Omerga Dist. Osmanabad-413606 (MS) India \\ Corresponding Author: stcharhan9@gmail.com
}

\section{Manuscript Details}

Manuscript Submitted :19/08/2018

Manuscript Revised : 25/08/2018

Manuscript Accepted : 30/08/2018

Manuscript Published : 15/09/2018

\section{$\underline{\text { Available On }}$}

https://plantaescientia.nebsite/ojs https://doi.org/10.32439/ps.vli03.55-59

\section{Cite This Article As}

Chathan ST, Darade MS, Devarkar VD. (2018) Mycopathological studies on Vigna radiata (L.) Wilczek (Green gram) from Patur, Dist. Akola (MS), India, Pla. Sci. 2018; Vol. 01 Iss. 03:5559.

\section{Copyright}

(C) The Author (s). 2018 Open Access

This article is distributed under the terms of the Creative Commons Attribution 4.0 International License http://creativecommons.org/licenses/by/4.0/

$\underline{\text { Indexed In }}$

$\underline{\text { Crossref, Index Copernicus International }}$ (ICI), Directory of Research Journal Indexing (DRJI), Scientific Indexing Services (SIS)

\begin{abstract}
Study of fungi infection from infected green gram plant was carried out in present identify. Various fungal pathogens were identified from green gram plants with respect to different localities and varieties at field condition. Selected samples were collected from regions of studied area. Total ten and eleven fungi were identified from tho variety of green gram AKM-9911 and AKM-9904 respectively. Green gram (Vigna radiata (L.) Wiczek.) is one of the most widely used pulse crop of India. It is widely cultivated in Maharashtra, Uttar Pradesh, Gujarat, Tamil Nadu, Andhra Pradesh and Bihar. It is cultivated in many tropical and subtropical regions of the norld including India and was also cultivated in ancient Indian.
\end{abstract}

Keywords: Mycopathological Studies, Vigna radiata (L) Wilczek, Green gram, AKM-9911 and AKM-9904, Patur 


\section{INTRODUCTION}

India is an agricultural country where economy is based on agriculture. Till recent past, before independence our agriculture depended on rains. The farmers used to grow their own material for cropping but after the technological evolution since the commence of $21^{\text {th }}$ century the scenario has changed as many hybrid and genetically engineered varieties of agricultural crop plants are commercialized and that are also used to grow by farmers. However, it has been observed that these varieties also showed susceptibility to variety of pathogens resulting into lesser yield. The amount of disease is generally referred to as disease intensity (Teng, 1985). On the other hand disease severity is determined by a function of degree of affection, colonization and damage of host tissue. Measurement of severity based on lesion number or lesion area may be less related to yield, but more to disease progress. Measurement of both actual and visible disease (Rouse, 1988) in terms of percent tissue affected and the green leaf area duration respectively, gives more precise conclusion on disease and yield loss in the presence of a pathogen. Fungi causes different diseases to crop plants.viz, Leaf spots, rust, smut, powdery mildew, downy mildew and wilt diseases are the common examples of fungal diseases. It has been observed that there are about 6000 rust fungi that attack wide range of seed plants and caused destructive diseases. Some common examples of fungal diseases are leaf spots of Mung bean.

Green gram botanically named as Vigna radiata (L.) Wilczek is one of the major pulse crop of India and cheapest source of plant protein. It is a short duration legume crop and cultivated norldwide for its dry seeds. Annual Mung bean production worldwide is around 2.5 to 3.0 million tones, harvested from about 5.0 million ha (Poehlman, 1991). India contributes about $45 \%$ of the production. It is widely cultivated in Maharashtra, Uttar Pradesh, Gujrat, Tamil Nadu, Andhra Pradesh and Bihar. The dried seeds of green gram contain $23.6 \%$ protein, $58.2 \%$ carbohydrates, $1.2 \%$ fats, $3.3 \% \%$ fibers and $4 \%$ minerals.

Green gram is one of the most important pulse crop. It is grown in almost all parts of the country and belongs to family Fabaceae. Mung bean is an excellent source of high quality protein. It is consumed in different ways as dal, halva, snack and so many other preparations. Ascorbic acid (Vitamin-C) is synthesized in sprouted seeds of mung bean. The leguminous crops have the capacity to fix-atmospheric nitrogen through symbiotic nitrogen fixation. It is also used as green manure crop. It is grown in summer and kharif season in northern India and in southern India (Yadava, 1992). The major fungal diseases which infect the Mung bean are Root rot - Macrophomina phaseolina (Tassi.) Goid.,
Web blight, Rhizoctonia solani Khun. - Thanatephorus cucumeris, Poudery mildew Erysiphe polygoni DC., Cercospora Leaf spot- Cercospora canescens and AnthracnoseColletotrichum dematium and C. lindemuthianum (Grewal, 1988). Moreover, seed infection of Rhizoctonia bataticola on M phaseolina ranges from 2.2-15.7\% which causes $10.8 \%$ in grain yield and $12.3 \%$ in protein content of seed in Mung bean showed that, due to changing climatic conditions, the pathogen attack on the Mung bean also differs (Kaushik et al, 1998). Mung bean is more susceptible to Cercospora leaf spot disease in humid conditions and the percentage infection may reach up to $60 \%$ in locally cultivated varieties leading to nearly 50-60\% yield loss. Chilkuri etal, (2012) studied the seed borne fungi in Green gram and subsequently determined their effect on seed germination.

The average yield of Green gram crop is very low mainly due to low inherent yield potential and susceptibility of the crop to disease (Thakur etal, 1977). Leaf spot disease caused by Cercospora canescens is a serious disease in the Green gram growing areas during the season (Bashir, 1985). Cercospora leaf spot is one of the important disease that causes serious losses to Green gram crop and 23\% losses in yield have been reported (Quebral and Cagampang, 1970). Maximum loss of $61 \%$ was observed in case of grain yield (Iqbal et al., 1995) Several workers had reported the effective control of the disease with the application of fungicides (Singh and Naik, 1977; Singh and Singh, 1978).

\section{MATERIAL AND METHODS}

\section{a) Isolation of fungi from infected plant parts of green gram}

Infected plant parts of tho Green gram varieties viz AKM9911 and AKM-9904 were collected from the region of Patur Taluka, Dist. Akola. The infected plant materials were collected from the agricultural field. Small pieces measuring $2 \mathrm{~mm}^{2}$, each of infected tissue were cut off from infected green gram plants with the help of sterile sharp knife. Pieces of diseased fruit were washed with tap water and surface sterilized with $1 \%$ Sodium hypochloride solution for $2 \mathrm{~min}$ and washed twice with sterilized distilled water and then dried using sterile filter paper. The infected plant parts were separately transferred to sterilized petri-dishes containing Potato dextrose agar (PDA) medium and incubated at $25^{\circ} \mathrm{C}$ for 10 days. Petri- dishes were observed daily and colonies of fungi were chosen. The isolated fungi were purified using single spore technique and then kept in a refrigerator on PDA medium (Gams et al., 1998). Pure colonies of fungal isolates nere identified according to Ellis (1971) .Symptoms nere confirmed by Koch's postulates. 
b) Study of symptoms of fungal diseases on greengram

Study of Symptoms were carried out on the different varieties of Green gram ie. AKM-9911 and AKM-9902

\section{c) Study of Pathogenicity}

Healthy plant part from each sample nere surface sterilized with $90 \%$ ethanol and incision were made on them using a sterile $4 \mathrm{~mm}$ cork borer, similar sterile cork- borer was used to cut pellets of agar containing the cultures of fungal mycelia of the isolates. These fungi nere then inoculated into the hole created on the healthy plant parts of green gram respectively in a laminar air flow chamber. The controls with incision but not inoculated by fungal pathogens were established. The inoculated seed and the controls were placed in a clean polythene bag each moistened with-net balls of absorbent cotton nool to create a humid environment and incubated at $28^{\circ} \mathrm{C}$ for 5 days. After 72 hours, the inoculated infected plant parts were observed for symptom development. The causal agents were re-isolated from the infected fruits and compared with the original isolates (Akinmusire, 2011).

\section{d) Method of Petri plate exposure}

The Petri dishes ( $9 \mathrm{~cm}$ - diameters) containing $20 \mathrm{ml}$ selected Potato Dextrose Agar (PDA) medium were exposed at 1 meter height from ground level in every cases for $15 \mathrm{~min}$. over green gram field every neek. The exposed Petri plates were brought to the laboratory and incubated in an inverted position at $28^{\circ} \mathrm{C} \pm 1^{\circ} \mathrm{C}$ for 7 to 8 days. The colonies developed were examined regularly, counted and identified. The fungal colonies were enumerated after their grouth on the petri plates.

\section{e) Identification of Fungus}

Identification of fungal colonies nere made by visual and microscopic examinations. Identification up to generic level was done with the help of standard mycological books and manuals (Ellis, 1971; Gams et. al. 1998). Details regarding the qualitative nature of the mycoflora, their incidence, abundance and percentage contribution were recorded. Identified fungal species photographed and presented in Plate I.

\section{OBSERVATIONS AND RESULTS}

In order to study the fungi associated with the green gram, the samples of infected green gram parts were collected from different agricultural field of Patur Taluka of Akola district. These infected samples were brought to the laboratory. Infected tissues of the plant were cut and sterilized with $0.1 \%$ Mercuric chloride, washed thrice with sterile distilled water and placed on PDA medium. After incubation period of seven days grown fungi were isolated and identified and results are noted in Table No.l

Table 1: Isolation of fungi from different varieties of Green gram

\begin{tabular}{|l|c|c|}
\hline \multicolumn{1}{|c|}{ Fungi } & Green gram varieties \\
\cline { 2 - 3 } & AKM-99ll & AKM-9904 \\
\hline $\begin{array}{l}\text { Alternaria solani (Ell. and Mart.) } \\
\text { J. \& G. }\end{array}$ & & + \\
\hline Aspergillus flavus Link. & + & + \\
\hline Aspergillus niger Tiegh. & + & + \\
\hline $\begin{array}{l}\text { Cercospora canescens Ellis \& G. } \\
\text { Martin }\end{array}$ & + & + \\
\hline $\begin{array}{l}\text { Chaetomium globosum Kunze ex } \\
\text { Fr. }\end{array}$ & + & + \\
\hline Cladosporium sp. & + & + \\
\hline $\begin{array}{l}\text { Colletotrichum } \\
\text { lindemuthianum Scrib. }\end{array}$ & + & + \\
\hline $\begin{array}{l}\text { Curvularia lunata (Wakker) } \\
\text { Boedjin }\end{array}$ & + & + \\
\hline \begin{tabular}{l} 
Erysiphe polygoni DC. \\
\hline Fusarium oxysporum f. sp.
\end{tabular} & + & + \\
\hline Fusarium solani (Mart.) Sacc. & - & + \\
\hline Helminthosporium sp. & + & - \\
\hline $\begin{array}{l}\text { Phytophthora nicotiande. Breda de } \\
\text { Haan. }\end{array}$ & + & + \\
\hline $\begin{array}{l}\text { Phizopus stolonifer (Ehrenb.) } \\
\text { Vuill. }\end{array}$ & + & - \\
\hline
\end{tabular}

$+=$ Presence of fungus,$-=$ Absence of fungus

The variety AKM-9911 gave fungi viz, Rhizopus stolonifer, Erysiphe polygoni, Aspergillus niger, Aspergillus flavus, Cercospora canescens, Cladosporium sp., Curvularia lunata, Fusarium solani, Helminthosporium sp., Phytophthora parasitica. The AKM- 9904 variety of green gram shown fungi such as Chaetomium sp., Erysiphe polygoni, Alternaria solani, Aspergillus niger, Cercospora canescens, Cladosporium sp., Colletotrichum lindemuthianum, Cunvularia lunata, Fusarium solani, Fusarium oxysporum, Phytophthora parasitica. (Table No.1)The diseases caused by fungal pathogens were found on both varieties of green gram.

\section{DISCUSSION}

The present report suggests variations in the composition of mycoflora in different varieties of green gram reflect the variable degree of resistance and susceptibility for the establishment of particular group of fungi in the varieties yielding maximum number of fungal species. On the 
contrary, the varieties with poor incidence of fungi represent their resistant capacity.

The presence of Fusarium in air over test field might be due to the prevalence leaf spot and top Necrosis disease in the field of green gram caused by Fusarium sp. Similar observations were reported by (Sreeramalu and Ramlingam, 1966; Mallaiah and Rao, 1980 and Singh, 1992). The prevalence of Colletotrichum in the infected parts of the crops in the present study might be due to the infection to the crops by Colletotrichum lindemuthianum. It caused Anthracnose disease to Green gram crops. Hartung et al., (1981) and Singh (1992) reported these spores from the air from the abroad and India respectively. It is clear from results that Curvularia lunata and Phytophthora parasitica filtrate showed minimum green gram seed germination. Similarly Curvularia lunata and Phytophthora parasitica drastically hampered the Green gram seed germination at $100 \%$ concentration. These results are agreed with results given by Haikal (2008). The presence of Cercospora in the present study might be due to the infection of green gram crop by Cercospora canescens caused the Cercospora leaf spot. Cercospora leaf spot is a devastating disease that causes qualitative and quantitative losses to the crop (Sivaprakasam, 1983). Several scientists have screened the number of fungicides against the fungal grouth. Efficacy of Daconil has been reported against Cercospora leaf spot on Mung bean (Iqbal et al., 1990) and mung bean anthracnose (Bashir et al., 1985).

\section{CONCLUSION}

It can be concluded that. the farmers should be scientifically acquainted and trained about disease cycle, Identification of symptoms of disease at an early stage, Field sanitary practices, Crop rotation systems, methods of intercropping, proper use of water to a specific interval etc. Are the aspects whose knowledge would be useful to farmers to avid problems of yield loss of agricultural crops.

\section{ACKNOWLEDGMENT}

The authors wish to express their gratitude towards Principal, G.N.A. Science College, Barshitakli and Head, Department of Botany, G.V.I.S.H, Amravati for theirs constant support and research facilities provided at respective institutions.

\section{REFERENCES}

Akinmusire, O. O., (2011) Fungal Species Associated with the spoilage of Some E dible Fruits in Maiduguri Northern E astern Nigeria. Advances in Environmental Biology, 5(1): 157-16.
Bashir M, Ahmad Z. And Ghafoor A., (2005): Sources of genetic resistance in mungbean and blackgram ag ainst Urdbean leaf crinkle virus (ULCV). Pak J Bot 37:47-51.

Chilkuri Ashwini, G.K. Giri, (2012) Detection and transmission of seed borne mycoflora in green gram and effect of different fungicides, International Journal of Advanced Research (2012), Volume 2, Issue 5, 1182-118.

Ellis, M. B., (1971) Dematiceous hypomycetes. Gub Internation, Wallingford.

Gams, W., Hoekstora, E. S. and Aptroot, A., (1998) CBS Course of mycology, $4^{\text {th }}$ Ed., Centrall bureau voorschimmel cultures, Baarm. The Netherlands.

Grewal, J. S., (1988) Disease of pulse crops. An overview. Indian Phytopathol. 41:1-14

Haikal, N. Z., (2008) Effect of filtrate of pathogenicfungi of soybean on seedgermination and seedling parameters. J. Apl. Sci. Res. 4(I): 48-52.

Hartung J. S., Burton C. L. and Ramsdell D.C., (1981) Epidemidogical studies of Blueberry anthracnose disease caused by Colletotrichum glocosporioides. Phytopath. 71: 449-453. http//www.apsnet.org/publications/phytopathology/backissues/Documents/1981Artic les/Phyto7ln04 449.PDF

Iqbal S. M., A. Ghafoor, M. Bashir and B. A. Malik, (1995) Estimation d losses in yield components of mung bean due to Cercospra leaf spot. Pakistan J. Phytopath. 7: 80-81.190

Iqbal, S. M., Malik, M. R. and Malik, B. A., (1990) Economics of foliar fungicides tocontrol Cercospora leaf spot diseases in mungbean. Samad J. Agric, 6: 485-490

Kaushik, C. D., Chand, J. N., Saryavir, (1998) Seed borne nature of Rhizoctonia bataticola causing leaf blight of mung bean. Indian. J.Mycol. Plant Pathol. 17 154-157.

Mallaiah, K. V. and Rao, A. S., (1980) Aerial dissemination of uredospores of groundnut; Proc. Indian Nath. Sci. Acad. B46 No. 2 pp, 215-222. (1980).

Poehlman, J. M, (1991) The mung bean Oxford and IBH Publishing Co. New Delhi. 375.

Quebral F. C. and I. C. Cagampang, (1970) Influence of Cercospora leaf spot control on yield of mung bean. Agriculture at los Banos, 10: 7-12.

Rouse, O. J., (1988) Use of crop growth-models to predict the effects of disease. Annual Review of Phytopathology 26: 183-201.

Singh S. J., ( 1992) Management of viral diseases of horticultural crops by use of oils. In: Sokhi SS, Chandel SS, Singh PP (eds) Progress in plant pathological research. Indian Society of Plant Pathologists, Ludhiana, pp 223-240.

Singh S. D. and S. M. Naik (1977) Field control of Cercospora leaf spot of urd by Fungi seeds. Indian J. Mycol. Pl. Pathol. 6. 99.

Sivaprakasam K., (1983) Efficacy of some chemicals in the control of blackgram (Vigna mingo (L.) Hepper) Cercospora leaf spot (Erysiphe polygoni DC.) Madras Agric. J., 70:95-96.

Sreeramalu, T. and Ramalingam, A., (1966) A two year study of the air spora of a paddy fieldnear Visakhapatnam. Indian J. Agric. Res. 36 111-132.

Teng, P. S., (1985) Construction of prodictive models: Forcasting Grops losses. Advances in plant Pathology. 1985, 3: 179-206.

Thakur, P. R, Patel, P. N. and J. P. Verma, (1977) Genetic relationship between reaction tobacterial leaf spot, Yellow Mosaic and Cercospora leaf spot diseases of mung bean (Vigna radiate L.). Euphytica, 26: 765-774. https:// doi.org/ 10.1007/ BF00021705

Yadava D. S., (1992) Mung bean pulse crops (Production-Technology) (l-stedn). Kalayani, Publication New Delhi, Ludhiana. 


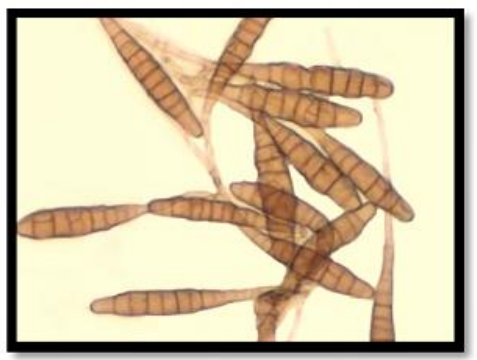

Alternaria solani (Ell. and Mart.) J. \& G.

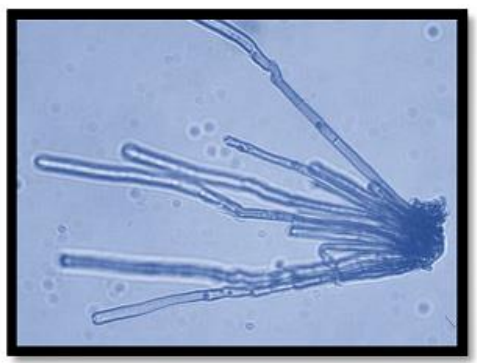

Cercospora canescens Ellis \& G. Martin
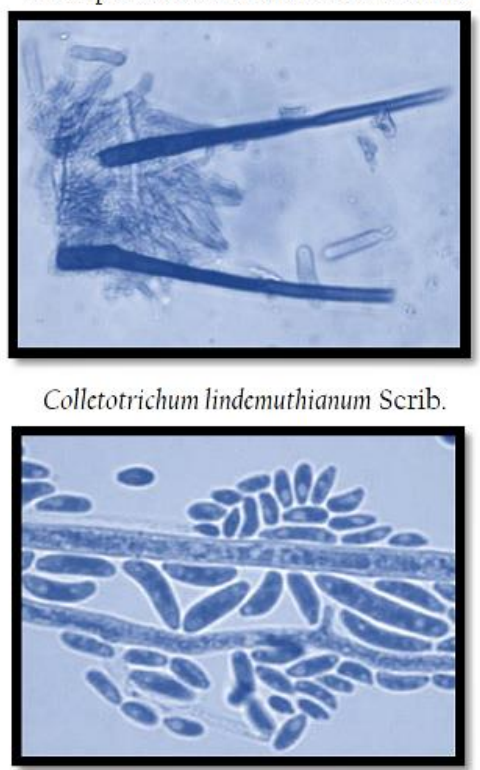

Fusarium oxysporum f.sp.

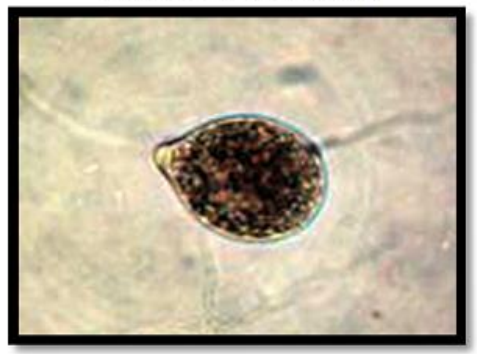

Phytophthora nicotianac. Breda de Haan.

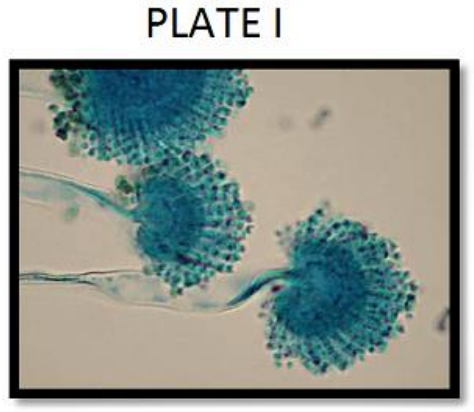

Aspergillus flavus Link

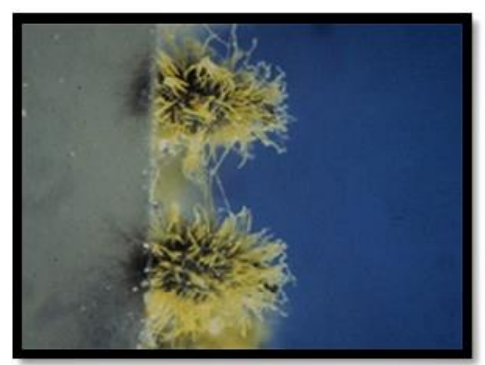

Chactomium globosum Kunze ex Fr.

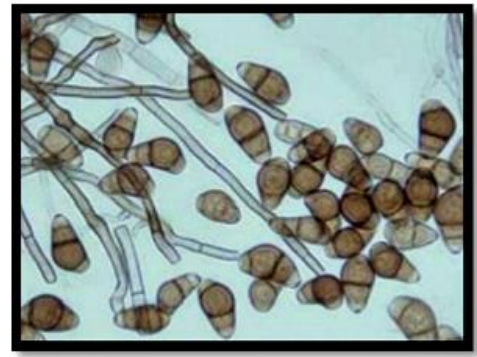

Curvularia lunata (Wakker) Boedjin

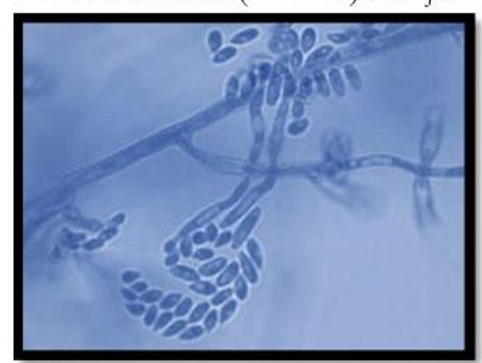

Fusarium solani (Mart.) Sacc

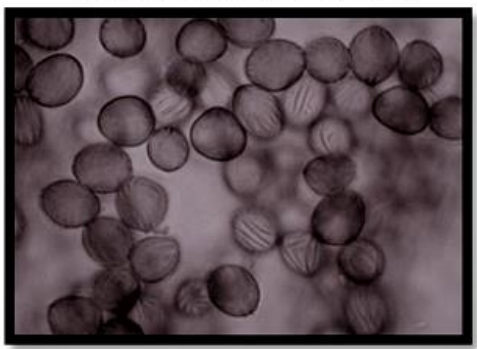

Rhizopus stolonifer (Ehrenb.) Vuill.

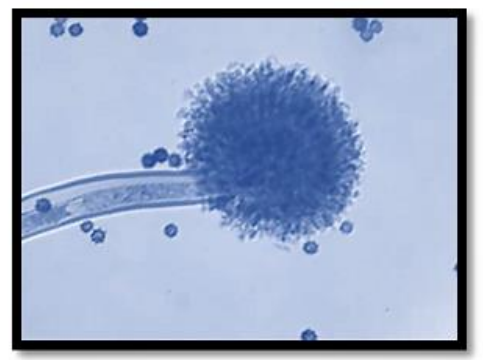

Aspergillus niger Tiegh
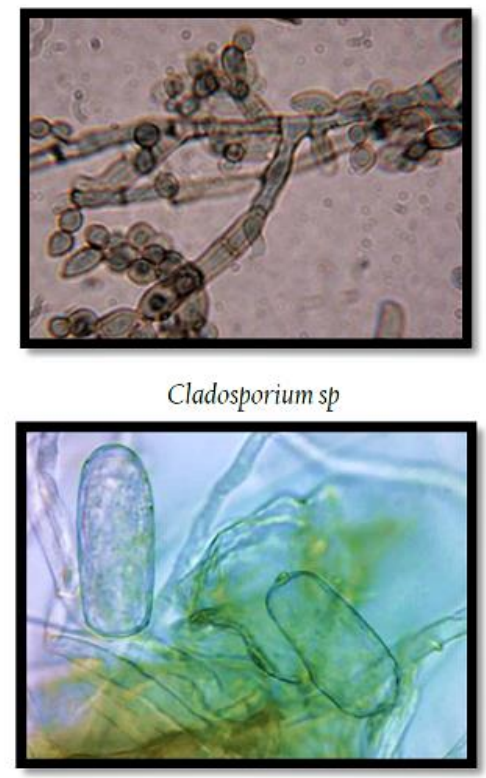

Erysiphe polygoni DC.
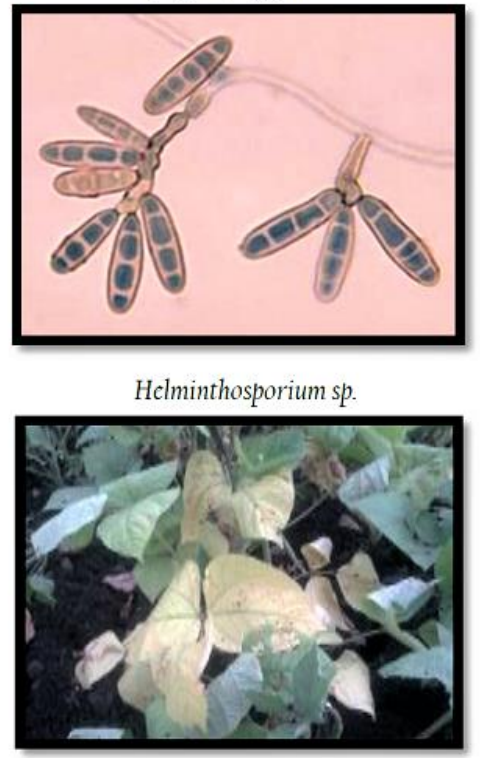

Infected plants of Green gram at field

0 2018| Published by Plantae Scientia 